\title{
Transfer of Language Skills (TLS): A Critical Literature Review
}

\author{
Salim Abu-Rabia1 ${ }^{1}$ Haneen Wattad ${ }^{2}$ \\ ${ }^{1}$ Faculty of Education, University of Haifa, Haifa, Israel \\ ${ }^{2} \mathrm{Al}$ Qasimi Academic College, Baka-Algarbiah, Israel \\ Email: Salimar@edu.haifa.ac.il
}

How to cite this paper: Abu-Rabia, S., \& Wattad, H. (2022). Transfer of Language Skills (TLS): A Critical Literature Review. Creative Education, 13, 98-111.

https://doi.org/10.4236/ce.2022.131007

Received: December 14, 2021

Accepted: January 15, 2022

Published: January 18, 2022

Copyright (อ 2022 by author(s) and Scientific Research Publishing Inc. This work is licensed under the Creative Commons Attribution International License (CC BY 4.0).

http://creativecommons.org/licenses/by/4.0/

\begin{abstract}
The purpose of the present study is to review the literature written about the concept of "Transfer of Language Skills". The focus of the review was on the methodology used on the studies, which tested the concept, and the way scholars interpreted their data. Furthermore, a suggested methodology was presented to test the transfer of language skills in a controlled experimental condition that permits a valid and reliable testing of the concept termed Transfer of language skills (TLS).
\end{abstract}

\section{Keywords}

Testing Cross-Language Transfer, Transfer of Language Skills (TLS), Intervention Programs, Cognitive Retroactive Transfer (CRT)

\section{Introduction}

The purpose of this review is to focus on studies that tested the term "Transfer of Language Skills" (TLS) from one language to another. Such empirical studies, which focused on TLS, their data analysis, will be discussed in relation to their drawn conclusions about the existence or non-existence of the TLS.

There is a need for more controlled experimental conditions in testing the TLS. Scholars conducted cross-cultural studies to test the above mentioned term TLS using different terms; relationship between first and second language; transfer of language skills; cross-language transfer; cross-linguistic transfer; cross-linguistic predictors, etc. (Durgunoĝlu, Nagy, \& Hancin-Bhatt, 1993; Cummins, 1989, 1979; Sun-Alperin \& Wang, 2011; Abu-Rabia \& Siegel, 2002; Gottardo, 2002; Hulme et al., 2002; D’Angiulli, Siegel, \& Serra, 2001 and many others). 
The present study discusses the above mentioned studies indicating their way of interpreting their data, the statistical analysis of their data, and the logical induction of their conclusions regarding the term TLS.

The present study discusses the term TLS from different orthographic aspects as indicated in the published empirical studies: TLS between languages of alphabetical orthographies; TLS between languages of opaque and shallow alphabetical orthographies; and TLS between languages with logographic and alphabetical orthographies. Further, the methodological and statistical analysis that leads to the TLS conclusions will be the focus of this paper. Finally, the suggested alternative methodology will be presented and enhanced with some empirical studies.

\section{Theoretical Frameworks of Cross-Language Transfer}

The transfer notion started with learning L2 grammar (Lado, 1957). According to Ludo's contrastive analysis hypothesis (Lado, 1957, 1964): He believed that learners capitalize on their native language, and their L2 acquisition can be predicted by their L1 level (König \& Gast, 2008). When certain features are shared, it may cause "positive transfer", and when there are no common features, it may cause "negative transfer".

The problem here is that, not all errors can be classified as positive or negative. A more complex argument is the interlanguage (Selinker, 1972), which suggests that errors may evolve from the development of the L2 learning process (Paradis, Genesee, \& Grago, 2011). Namely, more advanced interpretation of the L2 errors; the combination of transfer, development and interlanguage (Zdorenko \& Paradis, 2008).

\section{TLS between Alphabetical Orthographies}

Saiegh-Haddad and Geva (2008) reported a study that tested the contribution of the phonemic awareness to reading in two alphabetical languages: English and Arabic in Canada. Positive correlations were reported between Arabic and English phonemic awareness. Further, the English phonemic awareness was a strong predictor of reading words and pseudowords in both languages.

Wade Woolley and Geva (2000) reported a similar study that tested TLS phonemic awareness between English and Hebrew. The results indicated a positive correlation between the two phonological systems of both languages. Wade Woolley and Geva (2000) concluded that phonology was transferred between these two languages. Similarly, Bialystok et al. (2005) reported similar results between Spanish and English phonological processing.

Furthermore, Loizon and Stuart (2003) tested British five-year-old children learning English and Greek and another similar group of Greek children learning Greek and English. The researchers concluded that TLS existed between English and Greek. However, the Greek children did not show positive TLS between the languages. Similar to the British group results, Chiang and Rvachew 
(2007) reported that British children who were studying French as a second language, their English phonemic awareness predicted reading in French and was highly correlated with reading skills in French. Such correlation and regression analysis were enough proof for the existence of TLS, as reported by Chiang and Rvachew (2007).

Numerous studies have tested phonemic awareness TLS between Korean and English and scholars have concluded the existence of TLS between languages (Chiappe, Glaeser, \& Ferko, 2007; Kim, 2009; McBride-Chang et al., 2005; Wang, Cheng, \& Chen, 2006).

All the above mentioned studies used correlational computations and, based on significant positive correlations, they concluded the existence of TLS between languages. Further, they also used multiple regression analysis to test the prediction of the first language skills in acquiring the second language skills. Based on correlations and multiple regression analysis they concluded the existence of the TLS. This kind of analysis does not guarantee the existence or non-existence of TLS between languages. Correlations, either significantly positive or negative statistical correlations, do not indicate the existence of TLS. Proving the existence of TLS needs a better-controlled methodology.

Scholars used the term TLS based on correlations and inferred logically that if two or more language skills are significantly and positively correlated then it means that TLS did occur. This logic transferred between most empirical studies: namely, that correlational logic leads us astray. For example, López and Greenfield (2004) stated: "Within the last decade, research has emerged related to the effect of bilingualism on phonological awareness (Chiappe \& Siegel, 1999; Comeau, Cormier, Grandmaison, \& Lacroix, 1999; Durgunoĝlu, 1998). Primarily, this research has investigated a cross-language transfer effect in which knowledge and skills related to phonological awareness in one language can be applied to a second language" (López and Greenfield, 2004: p. 3).

Scholars considered their colleagues testing cross-language transfer when the term TLS, actually, is not being investigated. The only dependent variables under investigation are phonological awareness in both languages and the researchers logically inferred that the process is TLS. López and Greenfield (2004) continue: "Durgunoĝlu et al. (1993) were among the first to empirically test the idea that cognitive abilities in one's L1 can transfer to the same cognitive abilities in the second language" (López and Greenfield, 2004: p. 3).

The study of Durgunoĝlu et al. intended to test cross-language transfer using corrections and regression analysis. However, transfer of skills should be well controlled in an experiment showing clearly how transfer occurs while controlling for all intervention variables. Such an experiment was not in Durgunoĝlu et al's (1991) study.

Durgunoĝlu et al. (1999) admit this limitation at the end of their article: "Cross-language transfer needs to be investigated under well-specified conditions with well-specified tasks..." (p. 463). However, they themselves join the mainstream flaws of correlations and regression analysis claiming that they have 
located TLS, they stated: “...our results indicate that cross-language transfer can occur in word recognition. Both phonological awareness and word recognition skills in Spanish are predictive of word recognition in English...” (p. 463).

Numerous studies in the field followed the above-mentioned approach, relying on correlational analysis and regression analysis, and ultimately concluding the existence of TLS between languages (Cisero \& Royer, 1995; Durgunoĝlu et al., 1993; Comeau et al., 1999; D’Angiulli et al., 2001; Wang, Park, \& Lee, 2006; Gottardo, 2002; Lindsey et al., 2003; Manis et al., 1999; Abu-Rabia \& Siegel, 2002, 2003).

\section{TLS between Shallow and Opaque Orthographies}

Al-Tamimi and Rababi'Ah (2007) tested phonological skills among $1^{\text {st }}$ grade students in Arabic and English in Jordan. English is an opaque orthography while Arabic is considered a shallow orthography. The results indicated strong significant correlations between phonological skills in both languages, concluding the existence of TLS. Similar results in Arabic and English were obtained in Abu-Rabia and Siegel $(2002,2003)$ studies and similar conclusions were drawn.

Likewise, Kahn-Horwitz, Shimron and Sparks (2005) tested factors that influence bilingual Hebrew native speakers learning English. They have found that phonological awareness skills in Hebrew were highly correlated with the same skills in English. They concluded that TLS between Hebrew and English had been established and that phonological skills in Hebrew predicted reading in English. Further, the study of Kahn-Horwitz et al. (2005) gained support from the study of Abu-Rabia \& Snaitsky (2010) who found that phonological skills in Russian and Hebrew were highly correlated and both were highly correlated with the same skills in English as a foreign language (Bialystok et al., 2005). They all concluded that TLS between languages had occurred.

Numerous studies have tested the TLS of the phonological skills between Spanish as a language with transparent orthography and English with opaque orthography (Bialystok et al., 2005; Cisero \& Royer, 1995; Durgunoĝlu et al., 1993; Sun-Alperin \& Wang, 2011). All scholars have reported the existence of the TLS between the languages Spanish and English. All scholars have used correlational analysis and regression analysis. Based on these statistical analyses they reached the conclusion about the existence of TLS between languages.

Similar results were obtained by Mann and Wimmer (2002) in German and English; Caravolas et al. (2005) in Czech and English; da Fontoura and Siegel (1995) in Portuguese and English; Abu-Rabia (2001) and Abu-Rabia \& Sanitsky (2010) in Russian and English; D'Angiulli, Siegel and Serra (2001) in Italian and English; and Arab Moghaddam and Senechal (2001) in Persian and English; Russak and Saiegh-Haddad (2011) and Loizon and Stuart (2003) in Greek and English.

The above studies seem to be highly influenced by the assumption of Cummins $(1979,1984,1989)$ that skills of the first language are transferrable to the 
second language regardless of orthographic depth. Unfortunately, scholars have not yet succeeded in determining TLS between languages beyond correlations and/or regression statistical analysis.

In summary, all of the above studies have concluded the existence of TLS relying on correlational and/or regression analysis.

\section{TLS between Shallow Orthographies}

The same thinking pattern is popular among scholars who tested TLS among shallow orthographies. This theme of studies testing shallow orthographies receives theoretical support from the script-dependent hypothesis (Liberman et al., 1974; Lindgren et al., 1985) and from the interdependent hypothesis of Cummins $(1979,1989)$. This is to say that skills from the first and second languages enhance each other, and if both languages have similar writing systems then TLS will be easily transferred from one language to another.

Lefrançoise and Armand (2003) tested phonological awareness of bilingual Spanish children learning French as a second language, and they found high significant correlations between both phonological skills in Spanish and French.

Likewise, Leikin, Share and Schwartz (2005) found high significant correlations between phonological skills in Russian and Hebrew, two shallow orthographies. Both studies, Leikin et al. (2005) and Lefrançois and Armand (2003), used correlations and regression analysis to test the prediction of first language skills in reading the second language. Both studies concluded that TLS had occurred from the first language to the second language.

Similarly, Laurent and Martinet (2010) tested skills of children in their first language French and their second language Occitano, a language with a shallow alphabetic orthography. The results indicated positive significant correlations between skills of both languages. Similar results were obtained by Verhoeven (2007) among Turkish children learning Dutch as a second language in Holland. Furthermore, Lecocq et al. (2009) reported similar results among French children learning Dutch as a second language.

In conclusion, TLS was treated as such also in these bilingual studies, using the same methodological logic based on correlations and/or regression analysis.

\section{TLS between Logographic and Alphabetic Orthographies}

Similar methodological thinking accompanied bilingual logographic and alphabetic orthographies. Numerous studies tested phonological awareness TLS between Japanese and Chinese orthographies and alphabetic orthographies (Akamatsu, 1999, 2003; Cho \& McBride-Chang, 2005; Gottardo et al., 2001; Hamada \& Koda, 2010; Keung \& Ho, 2009; Knell et al., 2007; Luk, 2003; Wang et al., 2005). The results of the above studies indicated the occurrence of TLS between logographic and alphabetic orthographies.

The studies of Keung and Ho (2009) and Wang et al. (2005) indicated the occurrence of TLS. This result was based on positive correlations between English 
phonological awareness and logographic orthographies. Knell et al. (2007) reported similar results between Chinese and English orthographies.

Akamatsu (1999) reported results of poor TLS between Chinese and Japanese as the first language to English as a second language, and that both Chinese and Japanese participants were slow and less accurate in reading English words. This is to say that TLS did not occur, or occurred poorly, in this case. Similar results were reported by (Luk, 2003; Akamatsu, 2003; Bialystok et al., 2005; Hamada \& Koda, 2010; Koda, 2007).

The conclusions of the above-mentioned studies were based on correlations and regression analysis.

\section{Intervention Programs as a Suggested Methodology to Test TLS}

Although the previous studies claimed to test the term TLS from one language to another, and the studies presented in this paper are a good example of when one claims to test a concept, in fact, the scholars were testing something else-and so there exists a problem of the validity of testing. All the studies, which tested TLS between languages, were methodologically based on correlational analysis; such analysis does not prove the occurrence of the TLS phenomenon.

For a controlled methodology we have conducted a few studies to prove the occurrence of the TLS between languages (Abu-Rabia \& Abu-Rahmuon, 2012; Abu-Rabia et al., 2013; Abu-Rabia \& Shakkour, 2014; Feder \& Abu-Rabia, 2020, 2021). All the above-mentioned studies in this chapter are based on the following experimental paradigm: pre and post intervention programs. There were experimental groups and control groups. All of the participants of the different groups were either poor, dyslexic, or at-risk students. One of the above studies was the Feder \& Abu-Rabia (2021). The study tested TLS "in the opposite direction" from the additional language (second/foreign) to the first language, named in the research literature as "Cognitive Retroactive Transfer", CRT of language skills (see the above-mentioned studies). It claims that if there is an improvement in the individual's linguistic and metalinguistic skills in the additional language, a similar improvement is anticipated in the same skills in his/her first language too.

All the participants in the study (the experimental group and the control group) passed a series of exams for testing linguistic and metalinguistic skills in English and Hebrew language before and after the intervention program. The skills tested included: phonological awareness, morphological awareness, recognition and production, syntactic awareness, semantic awareness, orthographic knowledge, reading pseudowords, word recognition, reading fluency (in Hebrew, vocalized and non-vocalized), spelling and reading comprehension.

In the current literature review, we investigate studies that examine the TLS from the additional language to the first language and vice versa. We searched English databases (ERIC, PsycINFO, Psyc-Articles, Education full Text, Academic Search Premier) using the following keywords: Transfer of Language 
Skills, Testing cross language transfer, intervention programs, cognitive retroactive transfer (CRT), between the years 2010-2021. In the summarizing table we included articles from 2010 to 2020 . We found 9 new studies that met our review criteria, the main important data of the studies that investigated TLS are presented in Table 1.

The research findings confirmed that there is a significant difference in improving (the difference between the two time points) most of the linguistic and metalinguistic skills in the English and Hebrew language in the experimental group amongst the three reading groups (the dyslexic, poor and normal readers) as opposed to improving these skills amongst the three reading groups in the control group.

Furthermore, the findings confirmed the TLS from the additional language to the first language, which was termed CRT. Namely, TLS between English as a first language was transferred to Hebrew as a first language. Confirmation of the existence of the CRT of language skills occurred in reading accuracy of words and pseudowords, reading vocalized and non-vocalized test and reading fluency in the non-vocalized text. Furthermore, the researchers noted a higher trend of improvement of skills in Hebrew in the experimental group in which more skills in English were learnt.

The number of participants in the current research was 124, they were from the $6^{\text {th }}$ grade in five schools in the northern district of the country (in the towns of Nesher and Hadera), born in Israel and whose mother tongue was Hebrew, from a middle-class status who studied in the national elementary education system.

The experimental group consisted of 64 pupils, of them 22 dyslexic, 21 poor readers, and 21 normal readers who learned English as a second foreign language and whose mother tongue is Hebrew. An intervention program for improving linguistic and metalinguistic skills in English was taken by the experimental group.

The control group consisted of 60 pupils, of them 20 dyslexic, 19 poor readers, and 21 normal readers who learned English as a second foreign language and whose mother tongue is Hebrew. They had not participated in the intervention program and they studied according to the customary English program for pupils in the $6^{\text {th }}$ grades.

The intervention program in the English language was given to the experimental group based on research findings and centers for enforcement that surfaced from the test results. The intervention program lasted about three to four months in the school framework and included 20 - 25 classes that lasted about 45 minutes twice a week. English teachers gave the lessons in small groups at school during the school day. The teachers had received an explanation and guidance from the research editor. The intervention program built in the English language emphasized enforcing five central fields: 1) basing and enforcing control over reading decoding; 2 ) widening orthographic vocabulary in reading and writing; 3) instilling grammar rules (developing syntactic morphology awareness); 
Table 1. Recent studies on Transfer of Language Skills (TLS).

\begin{tabular}{|c|c|c|c|}
\hline Author/s (year) & Topic Research questions & Research Design & Statistical analysis \\
\hline $\begin{array}{c}\text { Feder \& } \\
\text { Abu-Rabia (2021) }\end{array}$ & $\begin{array}{l}\text { Will an improvement in linguistic and } \\
\text { meta-linguistic skills in English as a FL lead } \\
\text { to an improvement in Hebrew as the L1? } \\
\text { Which type of readers (with dyslexia, poor, } \\
\text { typical) will benefit more from the English } \\
\text { intervention program? }\end{array}$ & $\begin{array}{l}\text { Intervention program by } \\
\text { testing skills included } \\
\text { phonology, morphology, } \\
\text { syntax, semantics, orthography, } \\
\text { decoding, reading fluency, } \\
\text { reading comprehension, } \\
\text { dictation, and spelling. }\end{array}$ & $\begin{array}{l}\text { Linear regression } \\
\text { analysis was performed } \\
\text { to test the existence of } \\
\text { transfer from skills in } \\
\text { English to skills in } \\
\text { Hebrew }\end{array}$ \\
\hline $\begin{array}{c}\text { Abu-Rabia, } \\
\text { Shakkour, \& Siegel } \\
\text { (2013) }\end{array}$ & $\begin{array}{l}\text { Can linguistic and metalinguistic skills be } \\
\text { transferred from foreign language } \\
\text { (second language) to the first language } \\
\text { (the mother tongue)? }\end{array}$ & $\begin{array}{l}\text { Intervention program that } \\
\text { tested by experimental process } \\
\text { to test the } \\
\text { linguistic skills }\end{array}$ & t-test \\
\hline $\begin{array}{c}\text { Goodrich, } \\
\text { Lonigan, \& Farver } \\
\text { (2013) }\end{array}$ & $\begin{array}{l}\text { Do children with higher initial skills in } \\
\text { either L1 or L2 would benefit more from } \\
\text { an intervention designed to promote skill } \\
\text { development in the other language than } \\
\text { would children with lower initial L1 or L2 } \\
\text { skills (for all skills). } \\
\text { for those skills that are specific-language } \\
\text { independent (i.e., PA) }\end{array}$ & $\begin{array}{l}\text { Intervention program that test } \\
\text { the Vocabulary, Phonological } \\
\text { awareness and Print knowledge }\end{array}$ & $\begin{array}{l}\text { Regression analyses } \\
\text { and interactions }\end{array}$ \\
\hline Gonca (2016) & $\begin{array}{l}\text { Is there any effect of L2 on L1? Do L2 } \\
\text { reading skills influence L1 reading skills? } \\
\text { Do L2 learners develop their L1 reading } \\
\text { skills by having L } 2 \text { reading courses? }\end{array}$ & Intervention program & $\begin{array}{l}\text { parametric data analysis } \\
\text { t-test, and Levene's test. }\end{array}$ \\
\hline $\begin{array}{c}\text { Abu-Rabia \& } \\
\text { Shakkour (2014) }\end{array}$ & $\begin{array}{l}\text { Is there a transfer of linguistic and } \\
\text { meta-linguistic skills from L3 to L1 and } \\
\text { to L2? } \\
\text { Is there cognitive retroactive transfer } \\
\text { (CRT) of skills? }\end{array}$ & Intervention program & $\begin{array}{l}\text { Multivariate Analysis of } \\
\text { Variance (One Way } \\
\text { MANOVA) }\end{array}$ \\
\hline $\begin{array}{l}\text { Abu-Rabia \& } \\
\text { Bluestein-Danon } \\
\text { (2012) }\end{array}$ & $\begin{array}{l}\text { Whether an improvement in English as a } \\
\text { second language causes an improvement } \\
\text { among poor readers in Hebrew as the } \\
\text { first language? }\end{array}$ & Intervention program & $\begin{array}{l}\text { A nonparametric test } \\
\text { (Wilcoxon test) for } \\
\text { dependent samples. }\end{array}$ \\
\hline $\begin{array}{c}\text { Andreou \& } \\
\text { Segklia (2019) }\end{array}$ & $\begin{array}{l}\text { Will there be an improvement in L2 } \\
\text { decoding after the intervention in L2? } \\
\text { Will there be an improvement in L1 } \\
\text { decoding after the intervention in L2? } \\
\text { Will there be an improvement in L2 } \\
\text { spelling after the intervention in L2? } \\
\text { Will there be an improvement in L1 } \\
\text { spelling after the intervention in L2? }\end{array}$ & Intervention program & $\begin{array}{l}\text { A nonparametric test } \\
\text { (Wilcoxon test) for } \\
\text { dependent samples. }\end{array}$ \\
\hline Kim \& Piper (2019) & $\begin{array}{l}\text { Do literacy skills in English and Kiswahili } \\
\text { have bidirectional relations for Grade } 1 \text { and } \\
2 \text { children in Kenya? If they do, does the } \\
\text { nature of the bidirectional relations differ as } \\
\text { a function of instructional approaches and } \\
\text { environments (i.e., intervention condition } \\
\text { compared with control)? }\end{array}$ & Intervention program & $\begin{array}{l}\text { cross-lagged path } \\
\text { models with } \\
\text { auto-regressors } \\
\text { and correlations }\end{array}$ \\
\hline
\end{tabular}




\section{Continued}

\begin{tabular}{clll}
\hline & Do students benefit more from the two & & Descriptive statistics, \\
Abu-Rabia \& & $\begin{array}{l}\text { questionnaire completed by } \\
\text { learning process, or is it the same as if they } \\
\text { hanitsky (2010) }\end{array}$ & $\begin{array}{l}\text { Marents and students and } \\
\text { hadervention program. }\end{array}$ & $\begin{array}{l}\text { between groups, and } \\
\text { regression model }\end{array}$
\end{tabular}

$\mathrm{L} 1=$ The first language/The mother tongue; $\mathrm{L} 2=$ The second Language; $\mathrm{L} 3=$ The third Language; $\mathrm{FL}=$ Foreign Language.

4) instilling spelling rules; 5) developing reading fluency and reading comprehension.

To conclude, in order to test TLS between languages a well-controlled research paradigm should be applied, otherwise the goals of research studies are not fulfilled. Intervention programs are needed with pre and post-test and different experimental groups and the matched control groups. Testing should take into consideration the first language of the students.

This suggested methodology indicates in a very clear way that the empowerment that students received in specific linguistic items in the first language transferred from the experimental group. This gives a more valid research and results as compared to the old paradigm based on correlation as reviewed in the other sections of this paper.

\section{Conflicts of Interest}

The authors declare no conflicts of interest regarding the publication of this paper.

\section{References}

Abu-Rabia, S. (2001). The Role of Vowels in Reading Semitic Scripts: Data from Arabic and Hebrew. Reading and Writing, 14, 39-59. https://doi.org/10.1023/A:1008147606320

Abu-Rabia, S., \& Abu-Rahmoun, N. (2012). The Role of Phonology and Morphology in the Development of Basic Reading Skills of Dyslexic and Normal Native Arabic Readers. Creative Education, 3, 1259-1268. https://doi.org/10.4236/ce.2012.37185

Abu-Rabia, S., \& Bluestein-Danon, D. (2012). A Study into the Results of an Intervention Program of Linguistic Skills in English (L2) and Its Effect on Hebrew (L1) among Poor Readers: An Examination of the Cognitive-Retroactive Transfer (CRT) Hypothesis. Open Journal of Modern Linguistics, 2, 131-139. https://doi.org/10.4236/ojml.2012.24017

Abu-Rabia, S., \& Sanitsky, E. (2010). Advantages of Bilinguals over Monolinguals in Learning a Third Language. Bilingual Research Journal, 33, 173-199. https://doi.org/10.1080/15235882.2010.502797

Abu-Rabia, S., \& Shakkour, W. (2014). Cognitive Retroactive Transfer (CRT) of Language Skills among Trilingual Arabic-Hebrew and English Learners. Open Journal of Modern Linguistics, 4, 1-20. https://doi.org/10.4236/ojml.2014.41001

Abu-Rabia, S., \& Siegel, L. S. (2002). Reading, Syntactic, Orthographic, and Working Memory Skills of Bilingual Arabic-English Speaking Canadian Children. Journal of Psycholinguistic Research, 31, 661-678. https://doi.org/10.1023/A:1021221206119

Abu-Rabia, S., \& Siegel, L. S. (2003). Reading Skills in Three Orthographies: The Case of 
Trilingual Arabic-Hebrew-English-Speaking Arab Children. Reading and Writing, 16, 611-634. https://doi.org/10.1023/A:1025838029204

Abu-Rabia, S., Shakkour, W., \& Siegel, L. (2013). Cognitive Retroactive Transfer (CRT) of Language Skills among Bilingual Arabic-English Readers. Bilingual Research Journal, 36, 61-81. https://doi.org/10.1080/15235882.2013.775975

Akamatsu, N. (1999). The Effects of First Language Orthographic Features on Word Recognition Processing in English as a Second Language. Reading and Writing, 11, 381-403. https://doi.org/10.1023/A:1008053520326

Akamatsu, N. (2003). The Effects of First Language Orthographic Features on Second Language Reading in Text. Language Learning, 53, 207-231. https://doi.org/10.1111/1467-9922.00216

Al-Tamimi, Y., \& Rabab'Ah, G. (2007). The Relationship between Phonological Awareness and Word Reading. Poznań Studies in Contemporary Linguistics, 43, 5-21. https://doi.org/10.2478/v10010-007-0011-6

Andreou, G., \& Segklia, M. (2019). Cross-Linguistic Skills Transfer from the Second/Foreign Language to the First among Students with Learning Disabilities after an Intervention Program in the Second Language. Creative Education, 10, 1023-1036. https://doi.org/10.4236/ce.2019.105077

Arab Moghaddam, N., \& Senechal, M. (2001). Orthographic and Phonological Processing Skills in Reading and Spelling in Persian/English Bilinguals. International Journal of Behavioral Development, 25, 140-147. https://doi.org/10.1080/01650250042000320

Bialystok, E., Luk, G., \& Kwan, E. (2005). Bilingualism, Biliteracy, and Learning to Read. Interactions among Languages and Writing Systems. Scientific Studies of Reading, 9, 43-61. https://doi.org/10.1207/s1532799xssr0901_4

Caravolas, M., Volín, J., \& Hulme, C. (2005). Phoneme Awareness Is a Key Component of Alphabetic Literacy Skills in Consistent and Inconsistent Orthographies: Evidence from Czech and English Children. Journal of experimental child psychology, 92, 107-139. https://doi.org/10.1016/j.jecp.2005.04.003

Chiang, P., \& Rvachew, S. (2007). English-French Bilingual Children's Phonological Awareness and Vocabulary Skills. Canadian Journal of Applied Linguistics, 10, 293-308.

Chiappe, P., \& Siegel, L. S. (1999). Phonological Awareness and Reading Acquisition in English- and Punjabi-Speaking Canadian Children. Journal of Educational Psychology, 91, 20-28. https://doi.org/10.1037/0022-0663.91.1.20

Chiappe, P., Glaeser, B., \& Ferko, D. (2007). Speech Perception, Vocabulary, and the Development of Reading Skills in English among Korean- and English-Speaking Children. Journal of Educational Psychology, 99, 154-166.

https://doi.org/10.1037/0022-0663.99.1.154

Cho, J.-R., \& McBride-Chang, C. (2005). Levels of Phonological Awareness in Korean and English: A 1-Year Longitudinal Study. Journal of Educational Psychology, 97, 564-571. https://doi.org/10.1037/0022-0663.97.4.564

Cisero, C. A., \& Royer, J. M. (1995). The Development and Cross-Language Transfer of Phonological Awareness. Contemporary Educational Psychology, 20, 275-303. https://doi.org/10.1006/ceps.1995.1018

Comeau, L., Cormier, P., Grandmaison, E., \& Lacroix, D. (1999). A Longitudinal Study of Phonological Processing Skills in Children Learning to Read in a Second Language. Journal of Educational Psychology, 91, 29-43. https://doi.org/10.1037/0022-0663.91.1.29

Cummins, J. (1979). Linguistic Interdependence and Educational Development of Bilin- 
gual Children. Review of Educational Research, 49, 221-251.

https://doi.org/10.3102/00346543049002222

Cummins, J. (1984). Bilingualism and Special Education: Issues in Assessment and pedagogy. Multilingual Matter Ltd.

Cummins, J. (1989). A Theoretical Framework for Bilingual Special Education. Exceptional Children, 56, 111-119. https://doi.org/10.1177/001440298905600203

D’Angiulli, A., Siegel, L. S., \& Serra, E. (2001). The Development of Reading in English and Italian in Bilingual Children. Applied Psycholinguistics, 22, 479-507. https://doi.org/10.1017/S0142716401004015

da Fontoura, H. A., \& Siegel, L. S. (1995). Reading, Syntactic, and Working Memory Skills of Bilingual Portuguese-English Canadian Children. Reading and Writing, 7, 139-153. https://doi.org/10.1007/BF01026951

Durgunoĝlu, A. Y., Nagy, W. E., \& Hancin, B. J. (1991). Cross-Language Transfer of Phonemic A wareness. Center for the Study of Reading Technical Report, No. 541.

Durgunoĝlu, A. Y. (1998). Acquiring Literacy in English and Spanish in the United States. In A. Y. Durgunoglu, \& L. Verhoeven (Eds.), Literacy Development in a Multilingual Context (pp. 135-145). Erlbaum.

Durgunoğlu, A. Y., Nagy, W. E., \& Hancin-Bhatt, B. J. (1999). Cross-Language Transfer of Phonological Awareness. In American Educational Research Association, Apr., 1992, San Francisco, CA, US; Portions of This Research Were Presented at the Aforementioned Conference. Arena Press.

Durgunoĝlu, A. Y., Nagy, W. E., \& Hancin-Bhatt, B. J. (1993). Cross-Language Transfer of Phonological Awareness. Journal of Educational Psychology, 85, 453-465. https://doi.org/10.1037/0022-0663.85.3.453

Feder, L., \& Abu-Rabia, S. (2020). An Examination of Differences in Linguistic and Meta-Linguistic Skills in English (FL) and Hebrew (L1): Results of an Intervention program. The Journal of Educational Research, 113, 226-243.

https://doi.org/10.1080/00220671.2020.1782812

Feder, L., \& Abu-Rabia, S. (2021). Cognitive Retroactive Transfer of Language Skills from English as a Foreign Language to Hebrew as the First Language. Journal of Learning Disabilities, Article ID: 00222194211003820. https://doi.org/10.1177/00222194211003820

Gonca, A. (2016). Do L2 Writing Courses Affect the Improvement of L1 Writing Skills via Skills Transfer from L2 to L1? Educational Research and Reviews, 11, 987-997. https://doi.org/10.5897/ERR2016.2743

Goodrich, J. M., Lonigan, C. J., \& Farver, J. M. (2013). Do Early Literacy Skills in Children's First Language Promote Development of Skills in Their Second Language? An Experimental Evaluation of Transfer. Journal of Educational Psychology, 105, 414-426. https://doi.org/10.1037/a0031780

Gottardo, A. (2002). The Relationship between Language and Reading Skills in Bilingual Spanish-English Speakers. Topics in Language Disorders, 22, 46-70.

https://doi.org/10.1097/00011363-200211000-00008

Gottardo, A., Yan, B., Siegel, L. S., \& Wade-Woolley, L. (2001). Factors Related to English Reading Performance in Children with Chinese as a First Language: More Evidence of Cross-Language Transfer of Phonological Processing. Journal of Educational Psychology, 93, 530-542. https://doi.org/10.1037/0022-0663.93.3.530

Hamada, M., \& Koda, K. (2010). The Role of Phonological Decoding in Second Language Word-Meaning Inference. Applied Linguistics, 31, 513-531. 
https://doi.org/10.1093/applin/amp061

Hulme, C., Hatcher, P. J., Nation, K., Brown, A., Adams, J., \& Stuart, G. (2002). Phoneme Awareness Is a Better Predictor of Early Reading Skill than Onset-Rime Awareness. Journal of experimental Child Psychology, 82, 2-28. https://doi.org/10.1006/jecp.2002.2670

Kahn-Horwitz, J., Shimron, J., \& Sparks, R. L. (2005). Predicting Foreign Language Reading Achievement in Elementary School Students. Reading and Writing, 18, 527-558. https://doi.org/10.1007/s11145-005-3179-X

Keung, Y. C., \& Ho, C. S. H. (2009). Transfer of Reading-Related Cognitive Skills in Learning to Read Chinese (L1) and English (L2) among Chinese Elementary School Children. Contemporary Educational Psychology, 34, 103-112.

https://doi.org/10.1016/j.cedpsych.2008.11.001

Kim, Y. S. (2009). The Relationship between Home Literacy Practices and Developmental Trajectories of Emergent Literacy and Conventional Literacy Skills for Korean Children. Reading and Writing, 22, 57-84. https://doi.org/10.1007/s11145-007-9103-9

Kim, Y. S. G., \& Piper, B. (2019). Cross-Language Transfer of Reading Skills: An Empirical Investigation of Bidirectionality and the Influence of Instructional Environments. Reading and Writing, 32, 839-871. https://doi.org/10.1007/s11145-018-9889-7

Knell, S., MacLeod, S., \& Watson, S. (Eds.). (2007). Museum Revolutions: How Museums Change and Are Changed. Routledge. https://doi.org/10.4324/9780203932643

Koda, K. (2007). Reading and Language Learning: Cross-Linguistic Constraints on Second Language Reading Development. Language Learning, 57, 1-44.

https://doi.org/10.1111/0023-8333.101997010-i1

König, E., \& Gast, V. (2008). Reciprocity and Reflexivity-Description, Typology and Theory. In E. König, \& V. Gast (Eds.), Reciprocals and Reflexives (pp. 1-32). De Gruyter Mouton. https://doi.org/10.1515/9783110199147.1

Lado, R. (1957). Linguistics across Cultures. University of Michigan Press.

Lado, R. (1964). Language Teaching: A Scientific Approach. MacGraw Hill.

Laurent, A., \& Martinot, C. (2010). Bilingualism and Phonological Awareness: The Case of Bilingual (French-Occitan) Children. Reading and Writing, 23, 435-452. https://doi.org/10.1007/s11145-009-9209-3

Lefrançois, P., \& Armand, F. (2003). The Role of Phonological and Syntactic Awareness in Second-Language Reading: The Case of Spanish-Speaking Learners of French. Reading and Writing, 16, 219-246. https://doi.org/10.1023/A:1022874425314

Lecocq, K., Kolinsky, R., Goetry, V., Morals, A., \& Mousty, P. (2009). Reading Development in Two Alphabetic Systems Differing in Orthographic Consistency: A Longitudinal Study of French-Speaking Children Enrolled in a Dutch Immersion Program. Psychological Belgica, 49, 111-156. https://doi.org/10.5334/pb-49-2-3-111

Leikin, M., Share, D. L., \& Schwartz, M. (2005). Difficulties in L2 Hebrew Reading in Russian-Speaking Second Graders. Reading and Writing, 18, 455-472.

https://doi.org/10.1007/s11145-005-8919-4

Liberman, I. Y., Shankweiler, D., Fischer, F. W., \& Carter, B. (1974). Explicit Syllable and Phoneme Segmentation in the Young Child. Journal of Experimental Child Psychology, 18, 201-210. https://doi.org/10.1016/0022-0965(74)90101-5

Lindgren, S. D., DeRenzi, E., \& Richman, L. C. (1985). Cross-National Comparison of Developmental Dyslexia in Italy and the United States Child Development, 56, 1404-1417. https://doi.org/10.1037/0022-0663.95.3.482

Lindsey, K. A., Manis, F. R., \& Bailey, C. E. (2003). Prediction of First-Grade Reading in 
Spanish-Speaking English-Language Learners. Journal of Educational Psychology, 95, 482-594. https://doi.org/10.1037/0022-0663.95.3.482

Loizon, M., \& Stuart, M. (2003). Phonological Awareness in Monolingual and Bilingual English and Greek Five-Year-Olds. Journal of Research in Reading, 26, 3-18. https://doi.org/10.1111/1467-9817.261002

López, L. M., \& Greenfield, D. B. (2004). The Cross-Language Transfer of Phonological Skills of Hispanic Head Start Children. Bilingual Research Journal, 28, 1-18.

Luk, G. (2003). Exploring the Latent Factors Behind Inter-Language Correlations in Reading and Phonological A wareness. Dissertation, York University. https://doi.org/10.1080/15235882.2004.10162609

Manis, F. R., Doi, L. M., \& Bhadha, B. (1999). See Dick RAN: Rapid Naming and the Longitudinal Prediction of Reading Subskills in First and Second Graders. Scientific Studies of Reading, 3, 129-157. https://doi.org/10.1207/s1532799xssr0302_3

Mann, V.A., \& Wimmer, H. (2002). Phoneme Awareness and Pathways into Literacy: A Comparison of German and American Children. Reading and Writing, 15, 653-682. https://doi.org/10.1023/A:1020984704781

McBride-Chang, C., Cho, J. R., Liu, H., Wagner, R. K., Shu, H., Zhou, A. et al. (2005). Changing Models across Cultures: Associations of Phonological Awareness and Morphological Structure Awareness with Vocabulary and Word Recognition in Second Graders from Beijing, Hong Kong, Korea, and the United States. Journal of Experimental Child Psychology, 92, 140-160. https://doi.org/10.1016/j.jecp.2005.03.009

Paradis, J., Genesee, F., \& Crago, M. B. (2011). Dual Language Development and Disorders: A Handbook on Bilingualism and Second Language Learning. Paul H Brookes Pub Co.

Russak, S., \& Saiegh-Haddad, E. (2011). Phonological Awareness in Hebrew (L1) and English (L2) in Normal and Disabled Readers. Reading and Writing, 24, 427-442. https://doi.org/10.1007/s11145-010-9235-1

Saiegh-Haddad, E., \& Geva, E. (2008). Morphological Awareness, Phonological Awareness, and Reading in English-Arabic Bilingual Children. Reading and Writing: An Interdisciplinary Journal, 21, Article No. 481. https://doi.org/10.1007/s11145-007-9074-x

Selinker, L. (1972). Interlanguage. International Review of Applied Linguistics in Language Teaching, 10, 209-232. https://doi.org/10.1515/iral.1972.10.1-4.209

Sun-Alperin, M. K., \& Wang, M. (2011). Cross-Linguistic Transfer of Phonological and Orthographic Processing Skills from Spanish L1 to English L2. Reading and Writing, 24, 591-614. https://doi.org/10.1007/s11145-009-9221-7

Verhoeven, L. (2007). Early Bilingualism, Language Transfer, and Phonological Awareness. Applied Psycholinguistics, 28, 425-439. https://doi.org/10.1017/S0142716407070233

Wade Woolley, L., \& Geva, E. (2000). Processing Novel Phonemic Contrasts in the Acquisition of L2 Word Reading. Scientific Studies of Reading, 4, 295-311. https://doi.org/10.1207/S1532799XSSR0404_3

Wang, M., Cheng, C., \& Chen, S. (2006). Contribution of Morphological Awareness to Chinese-English Biliteracy Acquisition. Journal of Educational Psychology, 98, 542-553. https://doi.org/10.1037/0022-0663.98.3.542

Wang, M., Park, Y. J., \& Lee, K. R. (2006). Korean-English Biliteracy Acquisition: Cross Language and Orthography Transfer. Journal of Educational Psychology, 98, 148-158. https://doi.org/10.1037/0022-0663.98.1.148

Wang, M., Perfetti, C. A., \& Liu, Y. (2005). Chinese-English Biliteracy Acquisition: 
Cross-Language and Writing System Transfer. Cognition, 97, 67-88.

https://doi.org/10.1016/j.cognition.2004.10.001

Zdorenko, T., \& Paradis, J. (2008). The Acquisition of Articles in Child Second Language English: Fluctuation, Transfer or Both? Second language Research, 24, 227-250.

https://doi.org/10.1177/0267658307086302 